Susana (1950) y Viridiana (1961) de Luis Buñuel: personajes $y$ relatos bíblicos. El intercambio dialógico y la carnavalización

\author{
ISABEL LinColn \\ Strange Reséndiz \\ isabelincoln@hotmail.com
}

Universidad Nacional Autónoma de México, México

FECHA DE RECEPCIÓN septiembre 21, 2018

FECHA dE APROBACIÓN diciembre 18, 2018

https://doi.org/10.32870/ elojoquepiensa.v0i18.307
Resumen / En este artículo se analizan las películas Susana (1950) y

Viridiana (1961) de Luis Buñuel. En el primer caso, se examina la cinta a partir del intercambio dialógico bajtinaino y de la comparación con otras películas de su contexto, pero se profundiza en el estudio de la protagonista, Susana, una mujer que se confronta con el resto de los personajes que tienen lugar en la acción. Por otro lado, en el caso de Viridiana, se consideran lasformas del festejo carnavalesco bajtinaino que se presentan en el filme, a través del estudio de los personajes y de la construcción simbólica del relato. En ambos casos, se analiza la relación que existe entre el relato cinematográfico y el texto bíblico.

Palabras clave / Carnaval, dialogismo, personaje, filme.
Abstract / In this article, the films Susana (1950) and Viridiana (1961) directed by Luis Buñuel are analyzed. In the first case, the film is examined from the dialogic exchange of M. Bakhtin and from the comparison with other films of its context, but the protagonist, Susana, is studied in greater depth, because she is a woman who is confronted with the rest of the characters that take place in the action. On the other hand, in the case of Viridiana, we study the carnival forms of the Bakhtinan theory that appear in the film through the characters and the symbolic construction of the story. In both cases, the relationship between the film story and the biblical text is analyzed.

Keywords / Carnival, dialogism, character, film. 


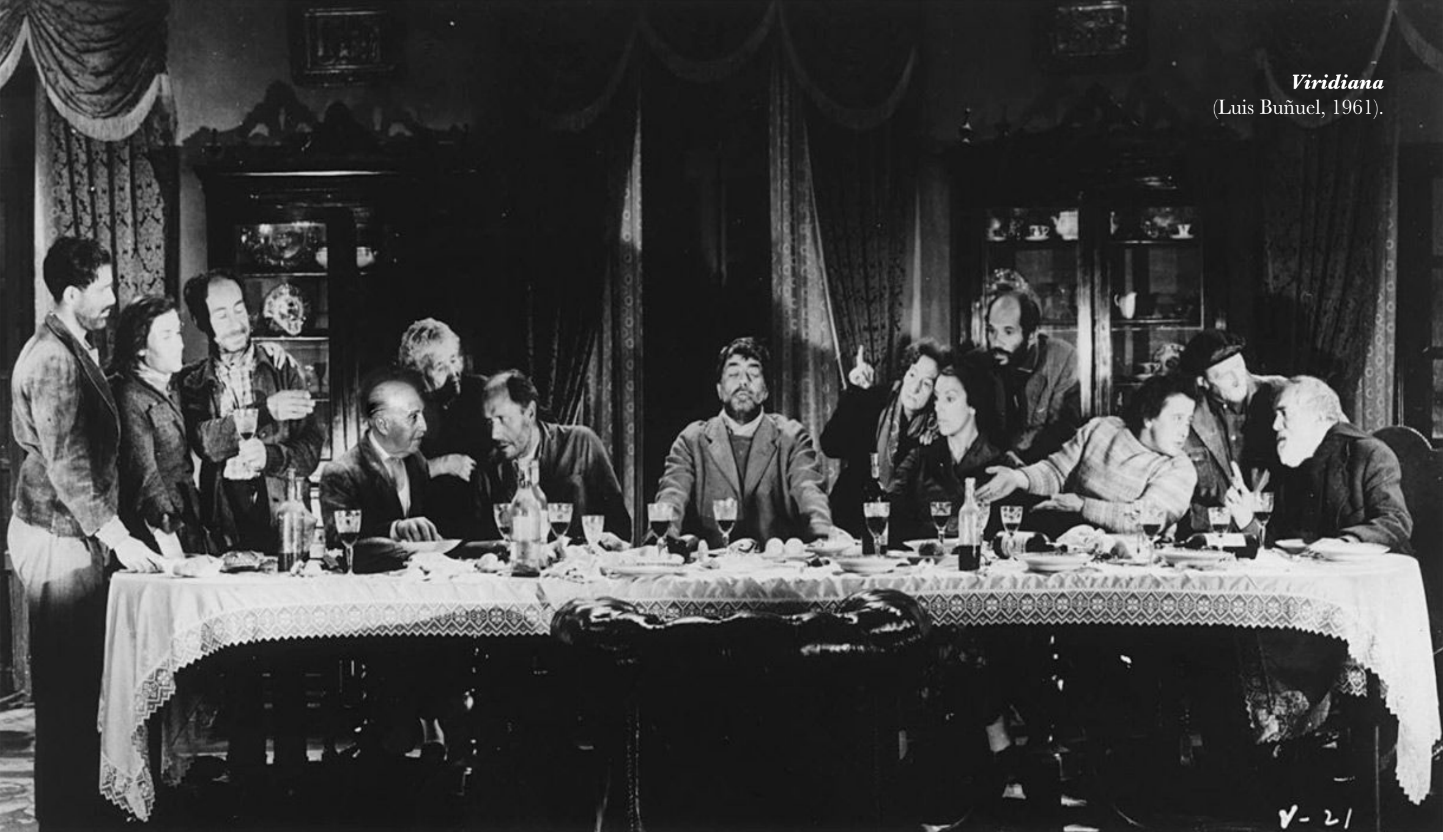

\section{UNA BREVE INTRODUCCIÓN}

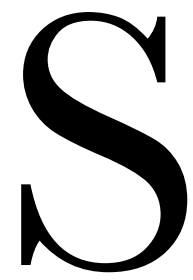

usana (1950) y Viridiana (1961), del director español Luis Buñuel (1900-1983), son dos obras distantes temporalmente. Empero, ambas dibujan una serie de coincidencias temáticas que es necesario estudiar: las dos cintas tienen como protagonistas a personajes femeninos; en ambas existe un vínculo con la religión y/o el relato bíblico; uno y otro texto confrontan al espectador y polemizan con otros textos a través del intercambio dialógico y el carnaval.

Es necesario iniciar con una breve descripción de la obra de Mijaíl Bajtín, un autor que se preocupó por discutir las cualidades del arte y de la cultura. Los trabajos del filósofo han creado expectativa en investigadores de la filosofía, la literatura y las artes en general. En el caso específico del estudio del cine, sus textos han llamado la atención de académicos como Robert Stam, por mencionar un ejemplo, quien publicó Subversive Pleasures: Bakhtin, Cultural Criticism, and Film (1992), libro en el que retoma algunas de las categorías desarrolladas por el filósofo. En otros trabajos, como "Hitchcock and Buñuel: Authority, Desire and the Absurd" (1991), Stam analiza 
el cine de Buñuel y Hitchcock e incorpora algunos de los términos empleados por Bajtín para el análisis de la cultura y las artes.

Bajtín también estudió la calidad del autor en la obra como un elemento fundamental en el análisis de la misma; según el filósofo, para comprender el texto y observarlo en todos sus aspectos, es necesario conocer la vida del creador, por ello, en este trabajo se incluye un apartado breve sobre la obra de Buñuel; en sus cintas existen una serie de fenómenos artísticos discursivos: estilizaciones, parodias, el relato oral y el diálogo.

En las páginas subsecuentes, se analizará el filme Susana a partir de la relación dialógica que establece con otros filmes de su contexto en México. Para ello, se expondrán brevemente las características del cine mexicano, a través del punto de vista de diversos autores. Las cualidades del relato en la película son un elemento importante a considerar, por lo que se realizará la revisión de algunas escenas en las que el personaje principal, Susana, confronta al resto de los personajes y, a la vez, al espectador. Empero, no perdemos de vista que el filme mantiene un vínculo con el texto bíblico, mismo que será retomado.

En la parte final del artículo, se estudiará el carnaval en Viridiana por medio del análisis de una serie de secuencias que son significativas debido a que los personajes se mofan de elementos sagrados o divinos, de tal manera que desafían a su contexto y al espectador.

En esta breve introducción es necesario mencionar que la justificación de la elección de los objetos de estudio radica en el hecho de que en estas dos películas, Buñuel participó de manera activa en la realización de los guiones; no se trata de adaptaciones literarias ni de historias que hubieran estado escritas cuando el director llegó a la filmación, como sucede con películas mexicanas en las que colaboró, como La ilusión viaja en tranvía (1954). Además, estos dos filmes reciben su nombre a partir de sus protagonistas; cabe anotar que, si bien Tristana (1970) también cuenta con un personaje principal femenino homónimo al del título de la película, esta es una adaptación de la novela de Benito Pérez Galdós.

\section{BREVES APUNTES SOBRE EL INTERCAMBIO DIALÓGICO Y EL CARNAVAL BAJTINIANO}

Los temas que le preocupan a Mijaíl Bajtín en sus diversas obras, también atañen al estudio del cine, ya que pertenecen al análisis del lenguaje y de la cultura. Irís Zavala, en el prólogo de El marxismo y la filosofia del lenguaje1, señala que "todos los lenguajes de una sociedad están en diálogo y polémica, todo lenguaje de un nivel algo más que elemental (...) elabora un nivel complejo de significación en la arena social" (1992, p. 17). Es decir, una obra de arte se relaciona con otros textos y contextos dentro de un acontecimiento dialógico. Bajtín estudia el lugar que el sujeto ocupa con relación a estos textos culturales y cómo entra en contacto y en diálogo con los acontecimientos, donde diversos lenguajes y discursos propician el surgimiento de distintas posiciones sociales. En este sentido, el cine es un texto y el espectador es

${ }^{1}$ Si bien este libro se publicó bajo la autoría V. N. Voloshinov (1895-1936), la autoría del mismo le pertenece a Mijaíl Bajtín. Zavala apunta que este libro salió a la luz en 1929, bajo el nombre de Voloshinov, sin embargo, el texto "pertenece a Bajtín o, cuando menos, se escribió bajo su inspiración directa" (Zavala, 1992, p. 11). La autora considera preciso subrayar las implicaciones de la autoría en este libro, por suponerlo una polémica ideológica, debido a que esta investigación, Bajtín abre las puertas al estudio interdisciplinario entre la lingüística, la retórica, la poética, la psicología, el lenguaje,el discurso y la teoría de la cultura: "muy al estilo siglo XXI (...) su teoría dialógica del lenguaje pueda servir de voz de apoyo al análisis retórico, la semiótica y al análisis cultural" (1992, pp. 12-15), cuestiones que atañen al estudio cinematográfico. 
el sujeto con el que el texto se relaciona; ambos pertenecen a un hecho dialógico.

Bajtín explica que "la situación social determina qué imagen, qué metáfora y qué forma de enunciado pueden desarrollarse a partir de una orientación entonacional de una vivencia dada" (Voloshinov, 1992, p. 125). En este sentido, observa el diálogo, no en el sentido estricto de la palabra, sino como toda una cadena discursiva. Una obra, ya sea literaria o fílmica, es un elemento de comunicación discursiva, una actuación discursiva fijada en un material, impreso o filmado, y está orientada a una percepción activa y a relacionarse con "una elaboración y una réplica interna”, que también afecta a otras formas de una esfera de comunicación discursiva. Toda expresión sígnica se construye en dos direcciones: hacia al sujeto, donde tiene la función de expresar los signos internos mediante los externos, y del sujeto a la ideología, donde es necesaria una comprensión de lo temático referencial. Todo signo interno se relaciona estrechamente con normas y valores éticos sociales; la comprensión del signo en la obra tiene un lazo indisoluble con lo social. En pocas palabras, las secuencias del discurso, las reelaboraciones de la expresión, las impresiones, y otros de los elementos mencionados, definen el intercambio dialógico.

Por otro lado, en La cultura popular en la Edad Media y el Renacimiento, Bajtín anota que el carnaval se manifiesta como un fenómeno cultural que rompe las barreras de los valores de la clase dominante: "los espectadores no asisten al carnaval, sino que lo viven, ya que el carnaval está hecho para todo el pueblo (...) no tiene frontera espacial. En el curso de la fiesta solo puede vivirse de acuerdo a sus leyes, es decir, de acuerdo a las leyes de la libertad" (2003, p. 13). A través del carnaval, se elabora una relación concreta entre realidad y juego, cuya celebración implica el hecho de que el hombre se libere de su comportamiento, gesto y palabra: "se liberan del poder de toda situación jerárquica (estamento, rango, edad, fortuna) que los suele determinar totalmente en la vida normal, volviéndose excéntricos e importunos desde el punto de vista habitual. La excentricidad es una categoría especial dentro de la percepción carnavalesca del mundo" (pp. 179180). Estos elementos son identificables en Viridiana, como se observará más adelante.

\section{SUSANA Y SU CONTEXTO}

En 1950, en el mes de junio, Luis Buñuel realizó Susana. El director apuntó en las entrevistas que le realizaron que lamentaba "no haber resaltado más la ironía, la broma" (De la Colina y Pérez Turrent, 1992, p. 100), porque el público pudo haberse tomado más en serio la historia debido a su final. Para el director, la película podía funcionar de dos maneras según el público que accediera a ella; podría llegar a verse "como una película inocente o moralmente tremenda" (p. 100). Declaró que es uno de los filmes en los que se permitió improvisar, al introducir una serie de elementos y diálogos que no formaban parte del guion original, como la araña que aparece cuando Susana (Rosita Quintana) está en la cárcel y el diálogo siguiente en el que la protagonista exclama: "Señor, yo también, aunque sea mala, soy una criatura tuya" (p. 100). Consideraba que en el argumento del filme Susana se presenta como un elemento erótico subversivo, debido a que era imposible pensar que la situación pudiera desarrollarse en el centro de una familia honesta, unida y decente: "la aparición de Susana es como la de un diablo seductor" (p.101). No obstante, al final todo vuelve a ser un paraíso. Buñuel que en esta y en otras de sus cintas, metía "recuerdos compartidos con algunas personas y claves inocentes. Si en Susana hay bromas, habré tenido buen 
cuidado de que la película entera no resultara una burla" (p. 105). Sin embargo, en su autobiografía, menciona que lamentaba no haber "subrayado la caricatura en el final, cuando todo termina milagrosamente bien" (1982, p. 197), debido a que un espectador "no avisado" podría llegar a tomarse seriamente el desenlace. El filme presenta una serie de relaciones complejas que, en gran medida, son determinadas por sus personajes femeninos.

Recordemos que el cine mexicano de las décadas de los 40 y 50 está fuertemente cargado con la ideología emanada del Nacionalismo Revolucionario. La mayor parte de las películas mexicanas de este contexto retratan temas y personajes simbólicos que se insertan en la dinámica cultural nacional. Algunos realizadores mexicanos del momento se ajustaron a los estándares de forma y contenido del cine nacional, a través de sus diversos géneros. Para comprender esta cuestión, es fundamental exponer las características generales de este cine mexicano, en el que Buñuel realizó Susana.

Carlos Mosiváis, en su texto Amor perdido (1997), menciona que estas décadas son un periodo de contradicción; por una parte, en los diarios se hablaba de la bonanza económica para el grueso de la población mexicana, pero, en realidad, existía una gran pobreza. Los gobiernos posrevolucionarios promovieron de manera contante la adhesión del Estado al nacionalismo, de tal manera que este pudiera conformarse a sí mismo ante la población en un sentido moral, a partir de la exposición de una serie de virtudes históricas que lo llevarían a mantener la empatía entre la sociedad y el Estado. En este sentido, en el cine y en otras formas de arte y comunicación aparecieron una serie de temas que fueron esenciales: "El machismo, en tanto espectáculo comercial, surge a fines de los treinta para, adornando esquemas de conducta, folclorizar y despolitizar" (Monsiváis, 1997, p. 31). Según señala Monsiváis, el "machismo-para-el-consumo" surgió por parte de la ideología burguesa, que consideraba que el exceso de "bravata física", haría que el pueblo se olvidara de la pobreza (p. 31). Así, el machismo fue considerado un valor cultural y una parte fundamental de los elementos que conformaron al hombre nacional durante gran parte del siglo veinte. En casi toda cinta mexicana el personaje principal tiene que ser macho y valiente, como buen mexicano; este es un elemento que definirá en gran medida el curso del cine nacional.

Julia Tuñón (1998) anota que la violencia masculina aparece como una característica que les gusta a las mujeres; los personajes femeninos anhelan que los hombres les hagan notar dicha violencia. Esto lo vemos en varios filmes del contexto, como en ;Ay Jalisco no te rajes! (Joselito Rodríguez, 1941), No basta ser charro (Juan Bustillo Oro, 1946), o Dos tipos de cuidado (Ismael Rodríguez, 1952), en las que el machismo parece justificar todas las acciones realizadas por los protagonistas.

$\mathrm{Al}$ respecto, Joanne Hershfield, en su ensayo "La mitad de la pantalla: la mujer en el cine mexicano de la época de oro" (2001), señala que las cintas de este contexto reforzaron la imagen de la mujer como madre virtuosa y sufrida, aunque el destino de las mujeres después de la revolución mexicana siguió siendo el mismo que antes de la lucha armada; se mantuvieron como sujetos oprimidos por nuevos discursos sociales y por nuevas representaciones culturales que dieron como resultado que la mujer funcionara en la narrativa cultural en dos sentidos, "virgen o la puta", como la buena o la mala (p. 129).

$\mathrm{Al}$ respecto, Carlos Monsiváis menciona que los melodramas se desarrollaron en un espacio fijo delimitado por la madre y la prostituta, respondiendo a las necesidades de la moral dominante. Existen tres grandes vertientes en este cine: el populismo de barriada, el género de las cabareteras y el género de amor familiar en peligro (1997, p. 169). 
A partir de lo anterior, es importante reflexionar en el impacto que tienen las cintas de Buñuel en este contexto, en el que el cine mexicano se ajustaba a los estándares del Nacionalismo Revolucionario, mientras sus películas creaban polémica en México y en el extranjero. Para ello, recurriré al texto "Autor y héroe en la actividad estética", contenido en Hacia una filosofía del acto ético. De los borradores y otros escritos (1997), de Mijaíl Bajtín, donde el autor explica que la reacción del autor condiciona la selección de las palabras del personaje, su entonación emocional, cognoscitiva, ética y temática, una serie de elementos que son valorados por el autor desde el punto de vista artístico y ético-cognoscitivo, "lo cual redunda en una forma de conclusión puramente estética" (p. 99). La reacción emocional y volitiva del autor con respecto a la obra se expresa en la propia elección del tema y del argumento, en la selección de las palabras y en la estructuración de las imágenes. En el drama, por ejemplo, "las imágenes expresan no solo la reacción del héroe, sino la reacción abarcadora del autor, su orientación con respecto al todo y a las partes" (p. 100). Esto nos lleva a pensar en cómo selecciona el artista, en este caso Buñuel, las imágenes para expresar sus intenciones artísticas y qué objetivo tienen las mismas en el relato. Los personajes que aparecen en el filme Susana reflejan la reacción del autor hacia la obra y sus partes. Bajtín explica que la totalidad del héroe puede tener un carácter puramente ético; pensemos en santidad, amor, razón de ser, persona, etcétera; el autor tiene una posición puramente existencial respecto a la obra y sus personajes (p. 101).

Bajtín considera que el análisis de la obra debe surgir del héroe y no del tema, porque, en caso contrario, "podemos perder el principio de plasmación del tema del hombre en cuanto a héroe potencial, podemos perder el centro de la visión artística y suplantar su arquitectónica concreta con un planteamiento prosaico" (p. 104). Buñuel realiza sus filmes pensando en sus héroes y ellos son los que causan un fuerte impacto en los espectadores y, al mismo tiempo, se contraponen a la temática de las películas producidas en el mismo contexto.

Susana es personaje femenino que sale de los estándares. En la película, encontramos esa imagen de la mujer seductora, muchas veces mostrada en la cinematografia nacional, pero que busca subrayar "la debilidad de la familia burguesa" (Hershfield, 2001, p. 148). Asimismo, vemos la imagen de la madre abnegada encarnada en doña Carmen (Matilde Palou), una mujer que lucha por salvar a su familia de la tragedia y arrojar fuera de su casa al "demonio", Susana, quien ha seducido a su hijo Alberto (Luis López Somoza) y su esposo Guadalupe (Fernando Soler). Las relaciones masculino/femenino son las que determinan las características de la familia mexicana en el cine nacional. Como señalamos, los hombres eran machos, llevaban el control de la casa, tomaban las decisiones. Las mujeres eran madres e hijas abnegadas, que guardaban la decencia y las buenas costumbres. Pero todo esto se fragmenta en Susana. Cuando doña Carmen le pide a su marido una explicación por haber despedido a Jesús (Víctor Manuel Mendoza), él le contesta: "De modo que otra vez tengo que darte explicaciones de mis actos. Está bien, no digas más. Voy a explicarte. Quise hacer un escarmiento para que nadie aquí crea que puede desobedecerme". Doña Carmen le dice que debió averiguar primero si ella lo había provocado o no, a lo que él responde: “ ¿No es para tanto que en mi propia casa se falte a la decencia, a la buena crianza, al respeto que se merece una mujer?". Sin embargo, esto es precisamente lo que hace don Guadalupe: no le falta al respeto a Susana porque ella no se siente agraviada, pero sí a su propia esposa, cuando, casi al final de la cinta, él mismo la corre de la casa para quedarse con la joven. 
Carlos Monsiváis explica que en Susana, "Buñuel nos niega el placer del melodrama clásico" (2001, p. 149). Esto es la cinta, la negación de los estereotipos del cine mexicano, de las formas del cine nacional y, especialmente, del drama familiar. En 1949, año de la realización de Susana, Ismael Rodríguez realizó La oveja negra, un drama familiar cuyo argumento se acerca al de la cinta de Buñuel; en él, Cruz Treviño Martínez de la Garza (Fernando Soler) es un padre de familia alcohólico y mujeriego, que mantiene un pleito constante con su hijo Silvino (Pedro Infante), quien le sugiere que tenga un mejor comportamiento por el bien de su madre. Sin embargo, el padre no cambia su estilo de vida; por el contrario, entra en conflicto con Silvino por la misma joven, Marielba (Amanda del Llano). Si bien en La oveja negra el conflicto es llevado al límite, todos los actos tienen sus consecuencias, por lo que el padre paga el maltrato que dio a su hijo y su esposa al final de la cinta.

No desearás a la mujer de tu hijo (1949), secuela de La oveja negra, también dirigida por Rodríguez, recupera al personaje de Cruz Treviño de la Garza, quien lucha por lidiar con el resultado de los actos realizados en la primera cinta.

De manera similar a las dos películas mencionadas de Rodríguez, el conflicto de Susana se desarrolla en el espacio rural; el filme puede considerarse parte del género del drama rural mexicano. En el filme encontramos una mezcla del machismo exacerbado, encarnado en una serie de personajes masculinos que entran en conflicto por poseer a la joven protagonista, que van desmantelando su núcleo familiar y que quebrantarán sus valores y principios. Lo curioso es que, el actor que representa el personaje del padre en La oveja negra y No desearás a la mujer de tu hijo es Fernando Soler, quien lleva el nombre de Guadalupe en Susana: se trata una cuestión que de alguna manera condicionará al personaje simbólicamente, debido a que lleva el nombre de una de las imágenes más representativas del catolicismo mexicano.

Las acciones de los personajes masculinos no tienen consecuencias en la película de Buñuel, a diferencia de lo que pasa con las películas de Rodríguez; don Guadalupe es recibido con una sonrisa por su esposa doña Carmen, al día siguiente de la salida de Susana de la casa, durante el desayuno, a pesar de que él la traicionó y engañó. En este sentido, desde el punto de vista de Bajtín (1997), la visión del creador prevalece en una obra artística. Buñuel — autor- busca rebasar los argumentos cinematográficos del contexto y exponer su visión del mundo a través de sus personajes.

Bajtín (1997) expone que una obra se compone por un contexto extra verbal que se divide en tres momentos: el primero es el horizonte espacial compartido por ambos hablantes; el segundo es el conocimiento y comprensión de una situación común; el tercero es la valoración compartida por ambos hablantes de esta situación común. Lo entendido y lo valorado en la obra se relaciona con el grupo al que pertenecen los hablantes, se trate de un mismo grupo, una clase social, etcétera. A partir del "enunciado vivo" se crean las potencialidades artísticas, "gérmenes de una futura forma y de un futuro contenido" (p. 123); el filósofo añade que el "tiempoespacio" artístico es irreversible y de carácter arquitectónico, adquiere una tonalidad emocional y volitiva, se mantiene como una "extratemporaneidad" y se extiende al infinito de manera total o parcial. Se trata del tiempo de su transmisión, de una representación espacial externa cargada de valores.

\section{SUSANA Y DOÑA CARMEN: EL ENFRENTAMIENTO}

El enfrentamiento entre Susana y doña Carmen sucede en un cuarto de trebejos que configura esa "pesadilla del demo- 
nio" de la que habla Felisa (María Gentil Arcos), la sirvienta, al final de la película. En la escena, observamos dos figuras femeninas que se enfrentan. A la izquierda está Susana con una actitud retadora, segura de su belleza y de su sexualidad, lleva un vestido blanco a la rodilla, el cabello suelto y los hombros descubiertos. En la contraparte, vemos a doña Carmen, quien duda en hacer uso de la fuerza para echar a la joven de la casa; la madre teme no actuar como una verdadera cristiana, una preocupación común en las madres del cine mexicano. La situación nos lleva a preguntarnos hasta qué punto doña Carmen aceptará los insultos de la joven y si tendrá el valor de echarla de la casa [FIGURA 1].

El momento expuesto es catártico; doña Carmen (en contrapicada) funge como esposa y defiende su hogar de los ataques de Susana (en picada) golpeándola con el fuete. Se trata, en este momento del relato, de una madre diferente en el cine mexicano, que no guarda silencio ante la destructora del hogar y que está dispuesta a defenderse con una sonrisa en los labios, pero siempre a escondidas de su esposo. De ahí que el enfrentamiento entre ambas mujeres no se da en la casa, que representa el ámbito de lo familiar por excelencia, sino en el cuarto de los trebejos, donde se suelen poner los objetos que no sirven o no se usan. Sin embargo nuestro entusiasmo por la actitud de doña Carmen termina pronto, cuando don Guadalupe entra en escena y prefiere a Susana sobre su esposa.

Entre claroscuros, la profecía de Felisa de que el diablo ha entrado en la casa se cumple. Doña Carmen deja de golpear a Susana como se lo pide su marido y acepta dejar el hogar familiar. Al terminar el conflicto, Jesús se presenta en el cuarto de Susana con la policía, que viene a arrestar a Susana para devolverla al reformatorio. Don Guadalupe sale de la habitación de la joven con la cabeza baja, no sabemos si por tristeza o por vergüenza. Antes de que la joven salga del cuarto intenta asesinar a doña Carmen con una hoz y es arrastrada por los cabellos fuera de la casa [FIGURA 2].

Susana determina todos los aspectos del filme; ella misma es el tema y el motivo. La diégesis se inicia con ella escapando de la correccional y, siendo congruentes con los personajes, la cinta debería terminar con ella siendo arrastrada por los cabellos fuera de la casa. No obstante, el desenlace de la cinta es, como lo señaló Buñuel, una "caricatura" de la institución
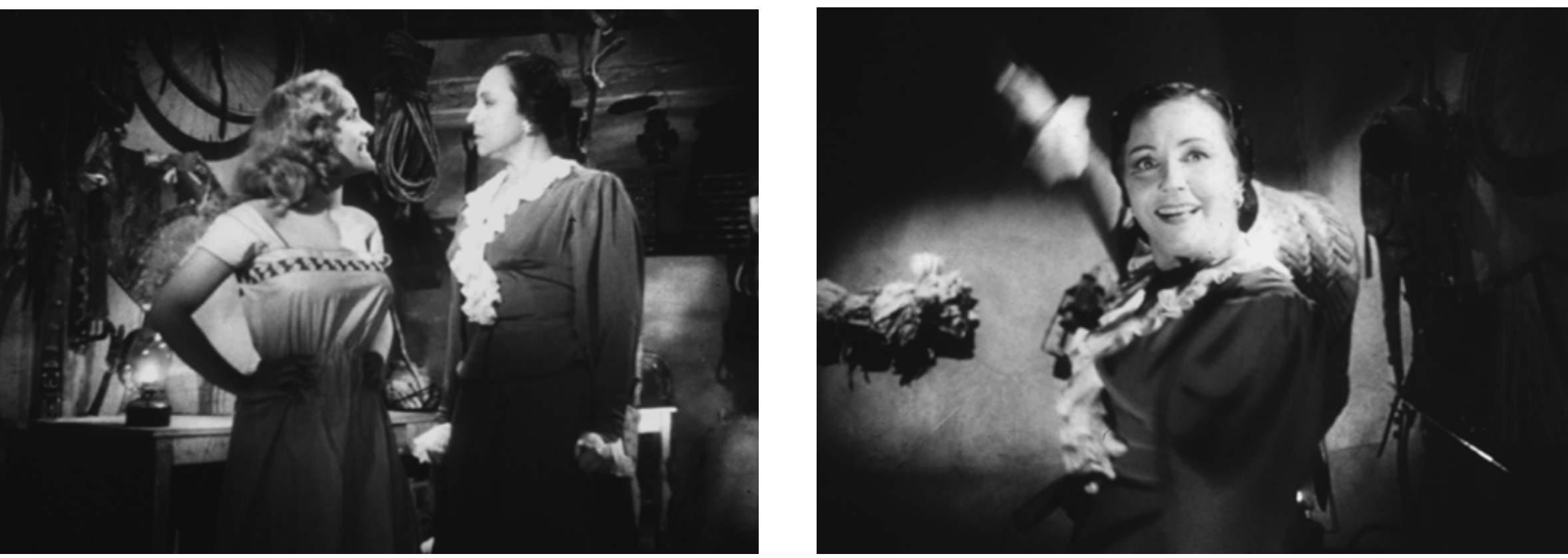
del matrimonio y de la familia, para un espectador que ha comprendido la realidad del relato, a través de la hipocresía de los personajes, de su humillación y sometimiento.

Don Guadalupe baja a desayunar y le dice a doña Carmen que sobre la cama ha dejado una carta en la que le explica todo lo que no se atreve a decirle a la cara; ella lo interrumpe y le pide a su hijo que no se siente a la mesa antes que su padre; Alberto se para con la mirada baja y besa la mano de su padre, quien pone una sonrisa en el rostro, mira a su esposa y se sienta a la mesa entusiasmado.

Encontramos, al fondo, una cruz que es, sin lugar a dudas, un signo ideológico que refuerza la noción que el director quiere transmitir en la escena: se trata de un hogar católico y las oraciones de doña Carmen fueron escuchadas. Recordemos lo que nos dice Bajtín: en una obra, el pensamiento del emisor y del receptor se relacionan con sistemas ideológicos en los que intervienen distintos discursos y realidades.

En este sentido, tanto el director como el espectador participan del sistema ideológico. Pero Buñuel deja al espectador la libertad de compartir su punto de vista sobre el final de caricatura o de adherirse al esquema a través de la idea de que todo ha vuelto a la normalidad. Esto representa una polémica que nos lleva a reflexionar en ¿por qué Buñuel califica de "caricatura" el final de la cinta? Según Bajtín (1997), en el estilo polémico, el autor coloca al héroe y al oyente en un mismo nivel. Por otro lado, en la sátira, el creador toma en cuenta al oyente como un sujeto cercano al personaje ridiculizado y no al autor como quien ridiculiza al personaje. Pero el personaje ridiculizado en el filme no es Susana, quien sale jalada por los cabellos, sino doña Carmen, quien ha sido humillada por su esposo y que, además, pone la otra mejilla y acepta su ofensa con una sonrisa en los labios. El destino de la madre en la película está determinado por la prerrogativa de
"Dios y hombre", tan popular en los hogares católicos y conservadores que se observaban en el cine mexicano [FIGURA 3].

Es fundamental observar que doña Carmen no solo le perdona la ofensa a su esposo, sino que está dispuesta a pelear con Susana hasta sus últimas consecuencias debido a que concibe que este acto le permitirá defender su hogar en todos los sentidos, incluso contra el "demonio". No obstante, después de que Susana sale de la casa, doña Carmen se percata de que la presencia de la joven le permitió reivindicarse como madre y como esposa, además de que le dio la oportunidad de reforzar su rol social; doña Carmen es tan buena madre y esposa, que puede olvidar las humillaciones que ha recibido y se configura a sí misma y ante el espectador como el personaje triunfante.

Doña Carmen recibió la mayor de las ofensas cuando su esposo hace evidente su deseo por Susana y sus intenciones de que se quede con él en la hacienda y que doña Carmen sea quien abandone la casa. La familia está fracturada y el sistema familiar se ha tambaleado (la madre encuentra a su marido besando a su amante en su propia casa). Susana es una película que rompe el esquema, rebasa los límites del melodrama ranchero y del drama familiar, no solo en contenido sino en la forma de su realización y, sin lugar a dudas, establece un intercambio dialógico, en el sentido bajtiniano, con el resto de los filmes de su contexto. Buñuel expone una serie de escenas que no se veían en el cine mexicano, con la madre tratando de defender su hogar y honor de manera feroz y fallando en el intento.

La película cierra con una imagen de la familia sonriendo en la ventana, don Guadalupe suspira y dice: "Parece que todo fue un sueño". A lo que Felisa responde: "El sueño era otro, señor, una pesadilla del demonio. Esta es la pura verdad de Dios". Susana es una cinta con un fuerte contenido católico; Felisa advierte que el diablo anda suelto y doña Carmen logra expulsarlo solo por fortuna. 


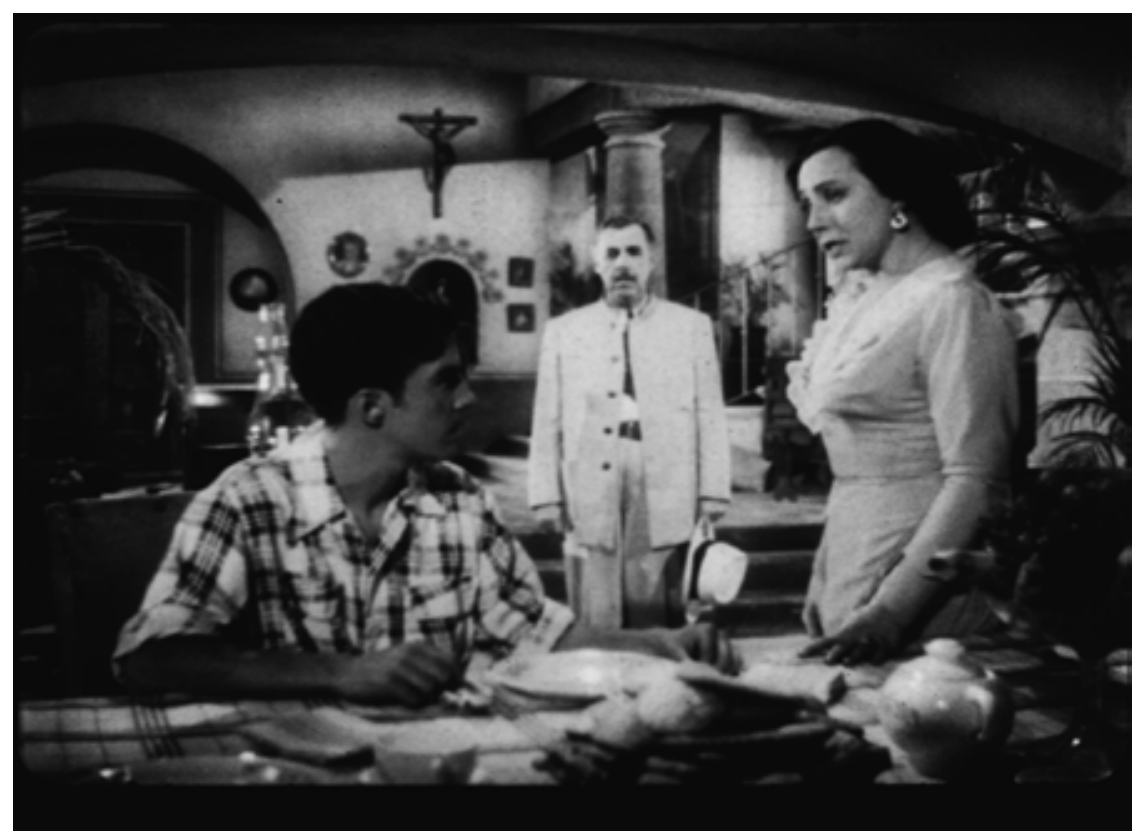

\section{SUSANA Y SU RELACIÓN CON EL RELATO BÍBLICO}

Si bien el argumento de Susana se ajusta a lo que se proyectaba en México - una familia ejemplar y amorosa, con un jefe y padre protector y proveedor; una madre, ama de casa y cariñosa; un hijo estudioso y obediente--, encontramos una protagonista malvada que jamás será redimida: Susana. El personaje es la mujer fatal que entra en el sistema familiar y ataca los valores de la ideología dominante.

Más allá de la relación que establece el filme con el contexto, no podemos perder de vista el vínculo que mantiene con La Sagrada Biblia; en la segunda parte del libro de Daniel, "Visiones proféticas", en el apéndice histórico de "Susana y los viejos", se relata la historia de esta hermosa mujer, esposa de Joaquín, quien es perseguida por dos jueces que visitaban su casa. En la historia se explica lo siguiente:

Los dos viejos la veían (...) les había nacido un vivo deseo de gozarla. Porque aquellos hombres habían pervertido su corazón (...) Estaban enfermos de pasión por ella (...) les daba vergüenza contarse aquella pasión (...) se pusieron de acuerdo acerca de la hora en que pudieran hallarla sola (...) corrieron donde estaba Susana y le dijeron: 'Mira, las puertas de la huerta están cerradas; nadie nos ve y nosotros tenemos ardiente deseo de poseerte; consiente en satisfacer nuestros
FIGURA 3.

Susana (Carne y demonio)

(Luis Buñuel, 1950). deseos, en ser nuestra. Si no, daremos testimonio contra ti' (...) Entonces Susana se puso a gritar en voz fuerte, y los dos viejos también se pusieron a gritar acusándola (...) La muchedumbre les creyó por ser viejos y aún jueces del pueblo, y a Susana la condenaron a muerte (Dn 13:1-41).

La casta Susana es acusada de adulterio y condenada por los viejos. Empero, en "Daniel libra a Susana de la muerte" se explica lo siguiente:

Entonces Susana exclamó en alta voz: 'Dios eterno, que conoces los secretos y sabes todas las cosas futuras antes de suceder, tú sabes que estos me han levantado un falso testimonio; ves que no he hecho nada de lo que estos pérfidamente han maquinado contra mí'. Oyó el Señor la voz de Susana, y cuando la llevaban al suplicio, excitó el espíritu santo de un muchacho llamado Daniel (Dn 13:42-45).

Daniel defiende a la joven y expone a los dos viejos, diciéndoles: "La hermosura de esa joven te fascinó, la pasión te torció el corazón” (Dn 13:56). En el relato bíblico, los viejos reciben el castigo que estaba destinado a Susana y ella regresa feliz al lado de su familia.

Sin lugar a dudas, existe un vínculo entre la fábula del texto bíblico y la que se expone en el filme; no obstante, Buñuel se toma la libertad de parodiar el relato bíblico. En el caso de la película, Susana es observada y deseada por los personajes masculinos que aparecen en la cinta. Desde su llegada a la 
casa, las miradas masculinas se posan en la joven medio desnuda, de tal manera, que el espectador se percata de que todos la desean. A partir del momento en que la joven se instala en la casa, desata el deseo y es asediada por los personajes masculinos.

El padre de familia, quien tiene el mayor compromiso de ser fiel a sus valores y principios, también cede ante los encantos de la muchacha. Don Guadalupe bien podría asemejarse al de los viejos representados en la Biblia; es el juez de su casa, es el proveedor y el portador de la sabiduría y, tal como sucede con el relato bíblico, la hermosura de esa joven lo fascina y la pasión le tuerce el corazón, al punto de despreciar a su propia familia.

Existe una cuestión que me parece fundamental subrayar: los viejos en la Biblia temen contarse el uno al otro la pasión que sienten por Susana porque les avergüenza poseerla. En el filme, Jesús teme enunciar la pasión que siente por Susana porque está avergonzado de ella y, si bien dice amarla y necesitarla, sabe que se está aprovechando de la posición en que la joven se encuentra al haber escapado del reformatorio, lo que se convierte en la oportunidad y el pretexto de poseerla, no en un único acto sexual, sino de manera permanente como su mujer, mas no como su esposa, porque en el filme, él nunca le pide matrimonio. Jesús observa a Susana como un animal del campo, como una yegua a la que tiene que domar.

Por su parte, Don Guadalupe, a pesar de que él es el juez del hogar y de la hacienda, ya que él es quien establece las normas sociales y las reglas a seguir en su territorio, no encuentra obstáculo en declarar sus sentimientos por Susana al final de la cinta, como resultado de diversas circunstancias, entre las que está el pretexto de que la esposa ha maltratado, golpeado y despedido a la joven, aunado a que Susana no ha demostrado ser una mujer liviana con otros delante de él. Don Guadalupe no ama a Susana pero desea poseerla; si bien las circunstancias se lo impiden a lo largo del relato, al final, su posición masculina, el hecho de ser hombre, es lo que le permite declarar sus intenciones hacia la joven, sin necesidad de darle explicaciones a los demás, de tal manera que se cumple una advertencia varias veces repetida en el relato: los hombres tienen a la mujer que desean. Sin embargo, pasan por alto las leyes de Dios, mismas que están presentes a lo largo de la cinta, cada vez que doña Carmen busca encontrar la solución.

En este sentido, Alberto es el único personaje dispuesto a declarar el amor que siente por la joven; se lo dice a su madre cuando esta le pregunta por su hosco estado de ánimo. La justificación narrativa de que el hijo declare sus sentimientos hacia Susana subyace, probablemente, en el relato bíblico; Alberto no siente vergüenza porla pasión y el amor que le ha generado la joven debido a que no desea el objeto prohibido, sino declarar abiertamente sus intenciones hacia una joven a la que considera buena y pura.

Si bien Susana está inspirada en la del relato bíblico, al ser una mujer bella y sumamente deseada, el personaje del filme supera por mucho las expectativas en lo que respecta a la respuesta femenina en torno al dominio masculino. La protagonista de la película no tiene nada de casta pero, al igual que la del libro de Daniel, ella ruega por su salvación y reza lo siguiente: "Dios de las cárceles, ten piedad de mí. Tengo tanto derecho como si fuera una víbora"; en respuesta, pareciera que Dios le otorgara la oportunidad de expiacióny Susana logra quitar los barrotes de su celda y alcanzar la libertad. La joven llega a la hacienda y es bien recibida por la familia. No obstante, desprecia esta oportunidad en un acto de maldad y soberbia, haciendo uso de su belleza y de su sexualidad. Pareciera que el personaje del filme toma las situaciones en sus manos y les extrae el mayor provecho posible, en actos malintencionados que llevan al espectador a preguntarse hasta dónde se atreverá a llegar. 
Un elemento importante es que la Susana del relato bíblico es una mujer pura e inocente; por el contrario, la protagonista del filme es una mujer inteligente que conoce la naturaleza machista de los hombres y lo que esta les obliga a hacer. Pareciera que dentro del filme, los personajes masculinos no tienen la posibilidad de pensar en lo que sucede a su alrededor y controlar sus deseos y sus instintos hacia las mujeres; tanto Jesús como Don Guadalupe, le dicen a Susana que no provoque a los hombres porque si ella sufre algún tipo de ataque, ellos no serán responsables. No obstante, Susana sabe cómo hacer uso de su sexualidad para controlarlos y sacarles el mayor beneficio posible; ella carece de inocencia y, al contrario del personaje del relato bíblico, parece tener un amplio conocimiento de la naturaleza masculina (estereotipada, según el contexto, como se explicó) que se muestra en la película.

Como vemos, el resultado en el pasaje bíblico es completamente distinto al destino que alcanza el personaje del filme. Sin embargo, es posible identificar las similitudes entre un texto y otro. Si bien, en ambos casos se trata de un personaje femenino que es acosado por su belleza, en la película, Susana se libera de las ataduras de su condición social y busca enfrentar a los acosadores a partir de las herramientas con las que cuenta: su sexualidad y su conocimiento de la naturaleza masculina. Susana trata de ganar una batalla. De hecho, la joven casi alcanza sus objetivos pero, casi de manera milagrosa, Jesús aparece en escena en el momento justo, como si Dios lo hubiese enviado al escuchar las oraciones de doña Carmen y Felisa. Esto nos lleva a reflexionar en las cualidades de un personaje dialógico, capaz de confrontar al espectador.

\section{VIRIDIANA Y SU CONTEXTO}

Después de trabajar una década en México, Luis Buñuel regresó a España en 1961 para realizar de Viridiana, una coproducción México-España. Buñuel ideó el argumento a partir de un recuerdo de su juventud, cuando estudió con los jesuitas y leyó la vida de Santa Viridiana en la revista La hormiga de Oro. Gustavo Alatriste le propuso realizar el filme en España, donde el director de Cinematografía aceptó la filmación solo si se cambiaba el final debido a que resultaba "tremendo" que una novicia terminara en el cuarto de un hombre (De la Colina y Pérez Turrent, 1996, p. 211); para consentir con la censura española, Buñuel introdujo en la secuencia a la joven en el cuarto del primo, pero con la criada y jugando al tute.

Para Buñuel, el deseo es un tema que está respaldado por el fetichismo, como se observa en la escena en que el personaje de don Jaime se prueba los zapatos de su difunta esposa. La caridad es también un tema principal que no solo es encarnado por Viridiana, sino por otros personajes como Jorge, quien le echa en cara a la protagonista que recoja a los mendigos, sin darse cuenta de que él tiene un acto caritativo al comprar el perro que va atado a la carreta. Para el director, este fragmento del filme no fue "un acto deliberado"; de hecho, declaró lo siguiente: "estoy contra la caridad de tipo cristiano" (p. 213). No obstante, señaló que la película no intenta criticar la caridad cristiana.

Viridiana expone una idea del mundo representada a través de los personajes, que son tan realistas que algunos críticos 
de cine, al estrenarse la película, aventuraron la idea de que los mendigos no eran actores sino, verdaderamente, mendigos; al respecto, Buñuel declaró que el único mendigo que participó en el filme es el que desarrolló el papel de leproso (p. 214). Este elemento de realidad que a Luis Buñuel le parecía "muy claro y fácil de comprender" (Buñuel, 1984, p. 230), resultó confuso para algunos espectadores del momento, como Gustavo Alatriste, quien vio la película seis veces antes de felicitar a Buñuel por haberla realizado (De la Colina y Pérez Turrent, 1996, p. 230). El erotismo es igualmente un tema importante; la mayor parte de los personajes se mueven, toman decisiones y actúan a partir de este elemento; se trate de don Jaime, Jorge, Enedina (Lola Gaos), el ciego (José Calvo) o la propia Viridiana (Silvia Pinal). No obstante, en estos personajes existe un acto ético o moral que determinará sus acciones, independientemente de sus deseos y de los sucesos que los mismos personajes no pueden controlar.

Viridiana provocó en España un escándalo bastante considerable, comparable al de La edad de oro, que me absolvió ante los republicanos establecidos en México. En efecto, a causa de un artículo muy hostil aparecido en L'Osservatore Romano, la película, que acababa de obtener en Cannes la Palma de Oro como película española, fue inmediatamente prohibida en España (...) El asunto causó tanto ruido, que Franco pidió ver la película. Creo incluso que la vio dos veces y que, según lo que me contaron los coproductores, no encontró en ella nada muy censurable (...) Viridiana permaneció prohibida en España (Buñuel, 1984, p. 230).

El filme es polémico; presenta a una serie de personajes complejos que representan, cada uno y en conjunto, una realidad humana, que puede resultar terrible de ver y aceptar para gran parte de los espectadores, debido a que estos personajes se burlan de las jerarquías sociales y de las instituciones.

\section{El CARNAVAL EN VIRIDIANA}

En el argumento de la película, Viridiana es una novicia que vive en un convento y a quien la madre superiora le pide que vaya a visitar a su tío Jaime (Fernando Rey). Al llegar a la casa, la joven es recibida por don Jaime; pasa algunos días en su casa y el tío le pide que se quede, se case con él y que no regrese al convento. Viridiana se niega y don Jaime la engaña haciéndole creer que la violó después de drogarla. El tío se suicida; Viridiana deja el convento y regresa a vivir a la hacienda con su primo Jorge (Francisco Rabal), misma que don Jaime les dejó en herencia a ambos. A partir de ese momento, la joven se dedica a auspiciar a los mendigos del pueblo, llevándolos a la casa y enseñándoles a seguir la obra de Dios.

Como vemos, la protagonista del filme se presenta como una joven caritativa y piadosa que quiere ayudar a los desprotegidos. En el Evangelio según San Mateo, Jesús le dice a sus apósteles:

Guidado con hacer vuestras buenas obras a la vista de los hombres con el fin de que os vean. De otra manera no recibiréis el premio de vuestro Padre. Cuando des limosna, no lo anuncies con la trompeta, como hacen los tramposos en las sinagogas o en las calles. Os aseguro que ya con eso quedan premiados (Mt 6:1-2).

En el mismo sentido, Viridiana desea ganar el reino de Dios incurriendo en el pecado de la vanidad. Las recomendaciones de Jesús sobre no hacer alarde de las obras de caridad, 
están acompañadas por la advertencia de que no será posible recibir el favor del Padre. Buñuel tal vez se inspiró en este evangelio para conformar al personaje, ya que Viridiana no sigue ninguno de los consejos del Señor; es decir, no hace su oración con honestidad y en privado, sino en el jardín de la hacienda, rodeada por los mendigos ${ }^{2}$, a plena luz del día y a la vista de todos los que viven ahí. En su afán por hacer penitencia, sintiéndose responsable de la muerte del tío, realiza un acto de caridad; sin embargo, el evangelio reza: "Pero cuando tú des limosna, que no sepa tu mano izquierda lo que hace la derecha, para que tu limosna se haga en secreto; y tu Padre, quien mira lo secreto, te recompensará" (Mt 6:3-4). No obstante, Buñuel estructura en el relato, una burla en torno a este personaje caritativo, quien hace sus buenas obras a la vista de los hombres.

Bajtín (2003) establece que la risa popular y sus formas son uno de los campos menos estudiados de la creación popular, ya que suelen ser relacionados comúnmente con el folclor. La risa se omite casi por completo de la cultura específica de la plaza pública; es un objeto digno de estudio desde el punto de vista cultural, histórico, folclórico o literario. La naturaleza específica de la risa popular "aparece totalmente deformada porque se le aplican ideas y nociones que le son ajenas pues pertenecen verdaderamente al dominio de la cultura y la estética burguesas contemporáneas" (p. 9). Por ello, el filósofo pretende establecer que la literatura de Rabelais es popular y tiene un carácter no oficial. Para aclarar esta cuestión, considera necesario emprender un estudio de las fuentes populares de Rabelais; para ello se propone plantear los problemas de la

${ }^{2}$ Cabe anotar que algunos de los nombres de los actores que representaron a los mendigos en la cinta no son fáciles de identificar en los créditos del filme, debido a que solo se utilizó como referencia la palabra "Mendigo" para definir a un personaje. Por ello, no se anota el nombre de todos los actores y actrices que aparecen en acción ya que no se pueden identificar de manera certera. cultura cómica popular en la Edad Media y el Renacimiento, en un afán por definir sus rasgos originales, a partir de las fiestas públicas carnavalescas. En esta diversidad de formas del festejo público existen tres categorías principales: la primera se relaciona con formas y rituales del espectáculo, como los festejos carnavalescos, las obras públicas representadas en las plazas públicas, entre otros. Igualmente, las “obras cómicas verbales (incluso parodias)", que pueden ser de naturaleza oral o escrita y encontrarse en latín o en una lengua vulgar. La última, son las "diversas formas y tipos de vocabulario familiar y grosero" (p. 10), que incluye insultos, juramentos, lenguas populares, etcétera.

En la secuencia de la cena de los mendigos, estos aprovechan la ausencia de los patrones para entrar a la casa y celebrar una fiesta en el comedor; ponen manteles largos, beben y comen haciendo uso de la cristalería de la casa; incluso crean un ambiente de festejo, tocando la guitarra, bailando y haciendo sonar en la tornamesa el Aleluya de Händel; además, se ponen la ropa de los patrones (el ajuar de novia de la tía de Viridiana), haciendo burla de la vestimenta [FIGURA 4].

Los personajes se mofan de las normas y de las jerarquías, así como de las deidades eclesiásticas. Cuando están todos reunidos en la mesa, Enedina les toma un retrato con una "máquina" que le regalaron sus padres, así que los mendigos se colocan en la mesa tal y como se encuentran los personajes en La última cena de Leonardo da Vinci, y al centro se encuentra el ciego. Justo cuando Enedina les dice, “iTodos quietos!” se oye cantar de un gallo, mientras la cámara hace un zoom in a la cara del ciego, que tiene una copa de vino frente a él. Enedina se levanta el vestido y toma el retrato ${ }^{3}$.

${ }^{3}$ Luis Buñuel declaró en Prohibido asomarse al interior que en la España de su tiempo era una broma común tomar un retrato cuando una mujer se levantaba la falda. 


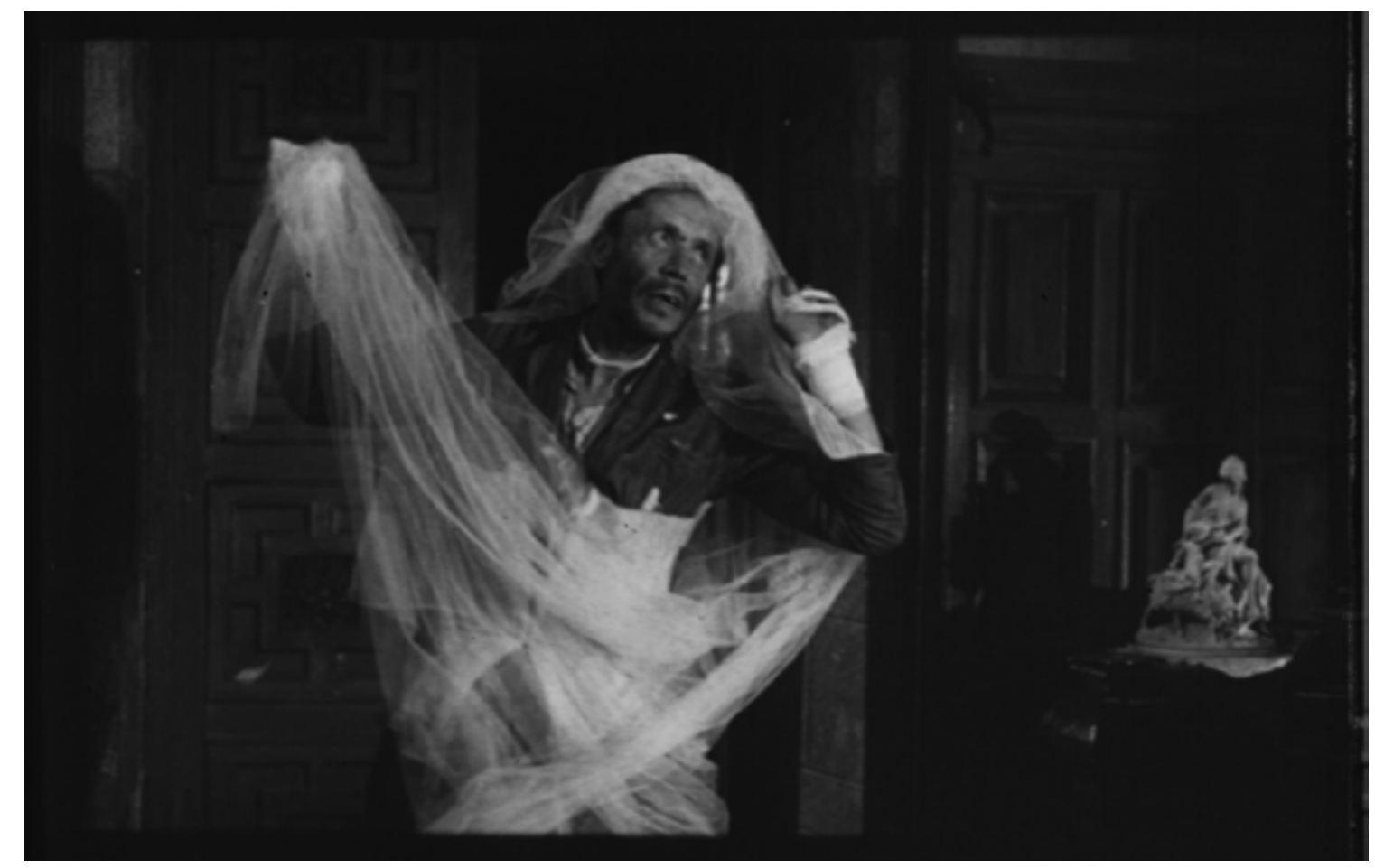

FIGURAS 4 y 6 .

Viridiana (Luis Buñuel, 1961).

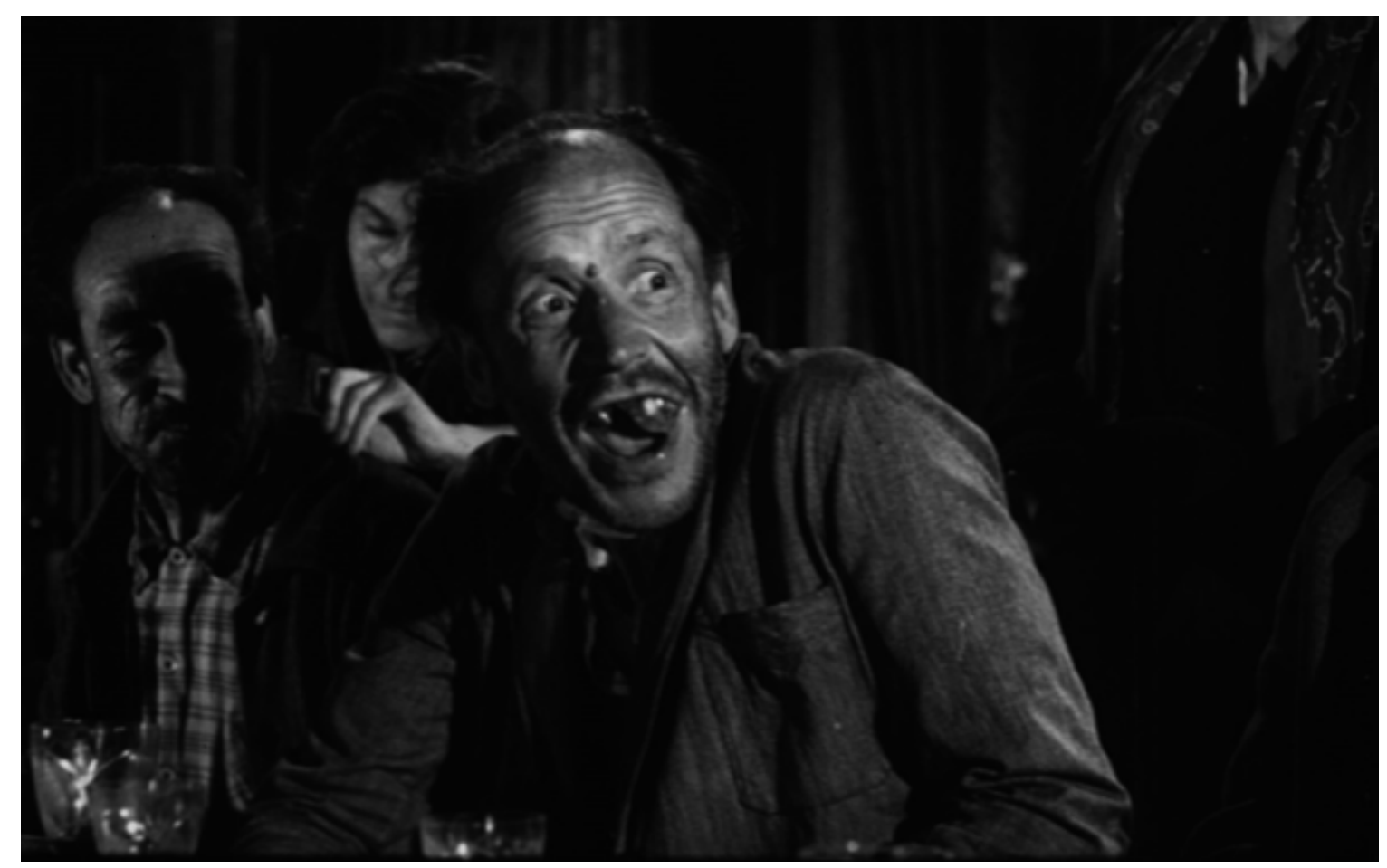


Según Bajtín, en las formas del espectáculo de los festejos carnavalescos aparecen los ritos y representaciones estaban organizados de manera cómica y eran marcadamente diferentes a las ceremonias oficiales ya que ofrecían una visión no oficial del mundo y del hombre, eran externas a la Iglesia y al Estado; representaban la oportunidad de acceder a "un segundo mundo y una segunda vida" (p.11). Se trataba de cultos cómicos que convertían a las divinidades en objetos de burla o blasfemia y existían de forma paralela a los ritos serios; también son festejos "decididamente exteriores a la Iglesia y la religión"; sus características los excusan del dogmatismo religioso y eclesiástico. En este sentido, el carnaval no es un espectáculo teatral y no pertenece al dominio del arte; está situado en la frontera del arte y la vida. Por estas razones, el carnaval ignora toda distinción entre actores y espectadores y también ignora la escena teatral. Los espectadores viven el carnaval, ya que no asisten a él como si se tratara de una representación teatral, "los que intervienen en el regocijo lo experimentan vivamente" (p. 12) y, lo que refuerza este factor, es el hecho de que no existe ninguna frontera espacial. Los mendigos olvidan su posición de clase y entran a la casa a disfrutar de sus comodidades. Pero no solo eso, se mofan de los dueños de la hacienda al ponerse el ajuar de novia de la tía y al bailar el Aleluya; en esta situación no puede existir un sentido serio. Esto es subrayado por las tomas que elige el director para enunciar la situación, a través de una serie de close ups al cuerpo de los mendigos, como la cara y los pies, acentúan lo grotesco, como se expone en las escenas narradas.

El carnaval se celebraba en las fechas relacionadas con los festejos religiosos, como la Navidad o la Pascua. Esto no sucede en la película, sin embargo, un elemento fundamental del carnaval es la risa como una característica de su vida festiva. La fiesta representa un descanso del trabajo y del mundo oficial. A diferencia de los festejos oficiales, que tenían el objetivo de "sancionar y fortificar el régimen vigente" durante la Edad Media; el carnaval representaba una liberación transitoria y "la abolición de las relaciones jerárquicas" (p.15), de las reglas y los tabúes. En la representación, los actores se movían de manera libre y familiar entre los asistentes al festejo y rebasaban las barreras de su condición social, su fortuna, empleo, edad y situación familiar. La disolución de las jerarquías en el carnaval permitía la elaboración de formas especiales de comunicación (del lenguaje y de los ademanes), que rompían la barrera entre los individuos y los liberaban de las reglas de conducta y de etiqueta [FIGURA 5].

El humor carnavalesco es festivo, "la risa carnavalesca es ante todo patrimonio del pueblo" (p.17); la risa es general y es universal. El mundo que rodea a los que participan es percibido desde una perspectiva jocosa y da lugar a una risa ambivalente: "alegre y llena de alborozo, pero al mismo tiempo burlona y sarcástica, niega y afirma, amortaja y resucita a la vez" (p. 17). La risa en el carnaval tiene el objetivo de mofarse de los mismos burladores. Contrariamente, la risa satírica de la era moderna emplea un humor negativo, una cuestión que no sucede con la del carnaval. Bajtín considera importante discutir el problema de la risa popular debido a que los estudios actuales la modernizan "groseramente", la interpretan en el espíritu de la literatura cómica moderna, ya sea como humor satírico negativo o como una risa dedicada únicamente a divertir, "ligera y desprovista de profundidad y fuerza" (p. 18), sin que su carácter ambivalente sea percibido por el receptor. En la película, después de que Enedina toma el retrato, algunos de los personajes bailan el Aleluya; de hecho, la pieza es el soundtrack de la cinta. Este elemento recuerda la irreverencia hacia lo religioso que existe entre los participantes del festejo. El Aleluya es el canto de alegría que entonan los católicos y que demuestra el júbilo a Dios; generalmente 
es interpretado durante la Pascua. En la escena, aunque los mendigos bailan la pieza con júbilo y con alegría, no lo hacen en un festejo religioso; José el leproso (Juan García Tienda) viste el velo y el corsé de novia en tono de mofa; entre los personajes que toman parte en la danza está Refugio, una mujer embarazada, quien lleva las medias a los tobillos, como lo muestra un close up a sus pies, y que nos recuerda a la hija de Ramona, Rita, que salta la cuerda mientras la mira don Jaime. La imagen de las medias al tobillo es un símbolo de la inocencia de la niña Rita, pero no determina las características del personaje. En contraparte, Refugio es una mujer embarazada que bebe, baila y golpea a las hijas pequeñas de Enedina; no es un personaje inocente; por el contrario, es cruel, quizás resultado de su ignorancia.

En la secuencia, existe otro elemento de la escena que no debemos olvidar; cuando Enedina toma el retrato a los mendigos, como mencionamos, se oye cantar de un gallo. En el Evangelio según San Juan (10:15-27), se explica cómo Simón Pedro negó a Jesús tres veces antes del canto del gallo. Este elemento sonoro, aunado a la composición de la secuencia, subrayan la burla y la risa de los participantes, entre los que se incluye al espectador de la película. Al respecto, podemos aventurar la hipótesis de que se trata de la negación misma de Jesús y de la mofa del relato bíblico, ya que el ciego está colocado al centro de la mesa, tomando el lugar de Jesús en la última cena [FIGURA 6].

Bajtín, al explicar las formas del festejo público y los tipos de vocabulario familiar y grosero, apunta que las groserías blasfematorias estaban dirigidas a las divinidades y constituían un elemento fundamental en los cultos cómicos más antiguos. En el carnaval, las blasfemias representaban ambivalencias, "desagradaban y mortificaban a la vez que regeneraban y renovaban" (2003, p. 19). Existían imágenes que se relacionaban con el inicio de la vida material y corporal, como el cuerpo, la bebida y la satisfacción de las necesidades naturales, incluida la sexual. Lo que sucede en el realismo grotesco tiene mucha relación con lo que se ha señalado hasta el momento; sus formas tienden a degradar, corporizar y vulgarizar. La risa popular emanada de las formas del realismo grotesco está ligada a lo corporal; esta risa degrada y materializa. La degradación de lo sublime no tiene un carácter formal y relativo dentro del realismo grotesco; lo mismo sucede en la parodia medieval: ambas formas se sustentan en significaciones absolutas. Aunque es importante anotar que Bajtín considera que el término "degradar" tiene una significación ambivalente debido a que implica, por un lado, entrar en comunión con la vida de la parte inferior del cuerpo, como el vientre y los órganos genitales, y también con actos como el coito, el embarazo o el alumbramiento: "la degradación cava la tumba corporal para dar lugar a un nuevo nacimiento. De allí que no tenga exclusivamente un valor negativo sino también positivo: es ambivalente, es a la vez afirmación y negación" (p. 25). Por lo tanto, el filósofo concibe el término de manera distinta a como ha sido observado comúnmente, como una manera de rebajar o de disminuir la dignidad de una persona.

Cuando Jorge entra a la casa y sorprende a los mendigos, la fiesta se termina, a partir de la toma en que él quita el disco del Aleluya de la tornamesa. En ese momento, uno de los mendigos lo amenaza con un cuchillo y el leproso lo golpea en la cabeza con una botella; Viridiana ingresa en la habitación y uno de ellos trata de violarla. Mientras ella pide ayuda, el leproso le dice: "No le va pasar nada, señorita, si todos somos gente de bien", en un tono de burla, que recuerda las palabras que Viridiana les había pronunciado a ellos cuando los invitó a su casa. Esta escena refuerza la idea de que el espectador también entra en contacto con la risa satírica de la era moderna, que emplea un humor negativo, que se coloca 
fuera del objeto aludido y se le opone, "lo que destruye la integridad del aspecto cómico del mundo" (Bajtín, 2003, p. 17).

Lo grotesco se incorpora al filme como un elemento esencial de la construcción narrativa. La cena de los mendigos deja de ser un festejo y se convierte en un hecho grotesco, respaldado por una serie de imágenes grotescas. El viejo que está encargado de poner el orden, es el primero en embriagarse y perder el control de la situación. Además, lo grotesco se ve reflejado cuando Refugio, embarazada, toma por debajo de los brazos una pequeña niña que llora y la sacude gritándole que se calle, por lo que la madre, Enedina, se acerca y pelea a golpes con Refugio; todo esto se da en el espíritu de la fiesta. En esta parte del relato se personifican los elementos que Bajtín enumera en relación con el realismo grotesco, principalmente, en la significación que tiene el concepto "degradar" en el texto bajtiniano, como un término ambivalente en el que se "cava la tumba corporal para dar lugar a un nuevo nacimiento, es afirmación y negación” (p. 28). Asimismo, la misma Viridiana experimenta diversos actos de degradación, el primero cuando despierta en su habitación en casa de don Jaime y este le dice que la drogó y abusó de ella, en un afán de obligarla a quedarse en la casa a su lado y ser su esposa, lo que la obliga a dejar el convento e iniciar una nueva vida. Pero no solo es degradada, sino que ella se siente humillada cuando el tío le confiesa que en realidad todo lo que le dijo fue una mentira, que no le ha faltado y que lo dijo en un afán por convencerla de no regresar al convento. $\mathrm{Al}$ mismo tiempo, cuando el mendigo intenta violarla, Viridiana trata de defenderse jalando la cuerda que el hombre lleva anudada a la cintura, como lo vemos en el close up, y que se trata de la misma cuerda con la que don Jaime se ahorcó, como símbolo que representa la degradación.

En el caso de Viridiana, el principio regenerador estriba en que la protagonista cambia su visión del mundo y pierde la distancia física que había establecido entre ella y los hombres; en este caso, su primo, lo que también es reforzado en la sonrisa que esboza Viridiana cuando él le pregunta que si ya se le pasó el susto. Lo grotesco es un fenómeno que se encuentra en un proceso de cambio y metamorfosis incompleta, en el estadio de la muerte y el nacimiento, del crecimiento y la evolución. Viridiana experimenta un comienzo y el fin de la metamorfosis.

\section{BreVES CONCLUSIONES}

Luis Buñuel es un artista que buscó establecer un contacto con el receptor; un autor que tenía algo que decir y lo hizo por medio de un objeto estético: el filme. Sus obras pueden comprenderse en distintos contextos y establecer un diálogo con sus receptores, en Susana y Viridiana, identificamos a dos personajes femeninos que confrontan al espectador y que, a su vez, establecen un diálogo con otros textos y contextos, de tal menta que la riqueza simbólica de sus películas crece ante la mirada nueva de espectadores ajenos al contexto de la realización de cada una de sus películas, lo que refuerza la idea bajtiniana de que existe una manera productiva constante, progresiva, de entender el arte.

Buñuel fue un realizador que siempre se pronunció ante el sistema a través de sus filmes; Susana hace una crítica social al sistema patriarcal de la familia mexicana, a través de un guion escrito por el mismo Buñuel, en que la protagonista del relato se enfrenta y se burla de la ideología dominante. El director juega con los personajes del filme y los pone al borde de sus instintos, en un espacio que parece contenerlos de manera catastrófica, de tal manera que solo la salida de Jesús de la hacienda permitirá resolver, de manera irónicamente afortunada, el destino de los participantes en la acción. Además, la relación que se establece entre el filme y el relato 
bíblico, nos permite comprender la contradicción de sus personajes y del mismo relato en sí.

Viridiana expone una serie de sucesos que están estrechamente relacionados con la risa y el carnaval. El espectador es partícipe de las acciones que realizan los personajes en el filme y reacciona ante las mismas; identifica las representaciones simbólicas religiosas a través de las burlas de los personajes. Apreciamos la estrecha relación que existía entre el director y el catolicismo, un vínculo que le permitió comprender la ideología y los preceptos católicos, y confrontarlos artísticamente.
El presente artículo analizó dos filmes fundamentales de Buñuel, cuyas protagonistas son distantes y disímbolos, pero que se erigen como sujetos autónomos que se desenvuelven en el espacio del relato,confrontando de manera constante a su contexto, a los otros personajes que toman parte de la acción y, en consecuencia al espectador. Sin duda, se trata de dos películas canónicas de las que aún queda mucho por decir. Este breve artículo analiza algunas de sus particularidades a través del intercambio dialógico y la carnavalización.

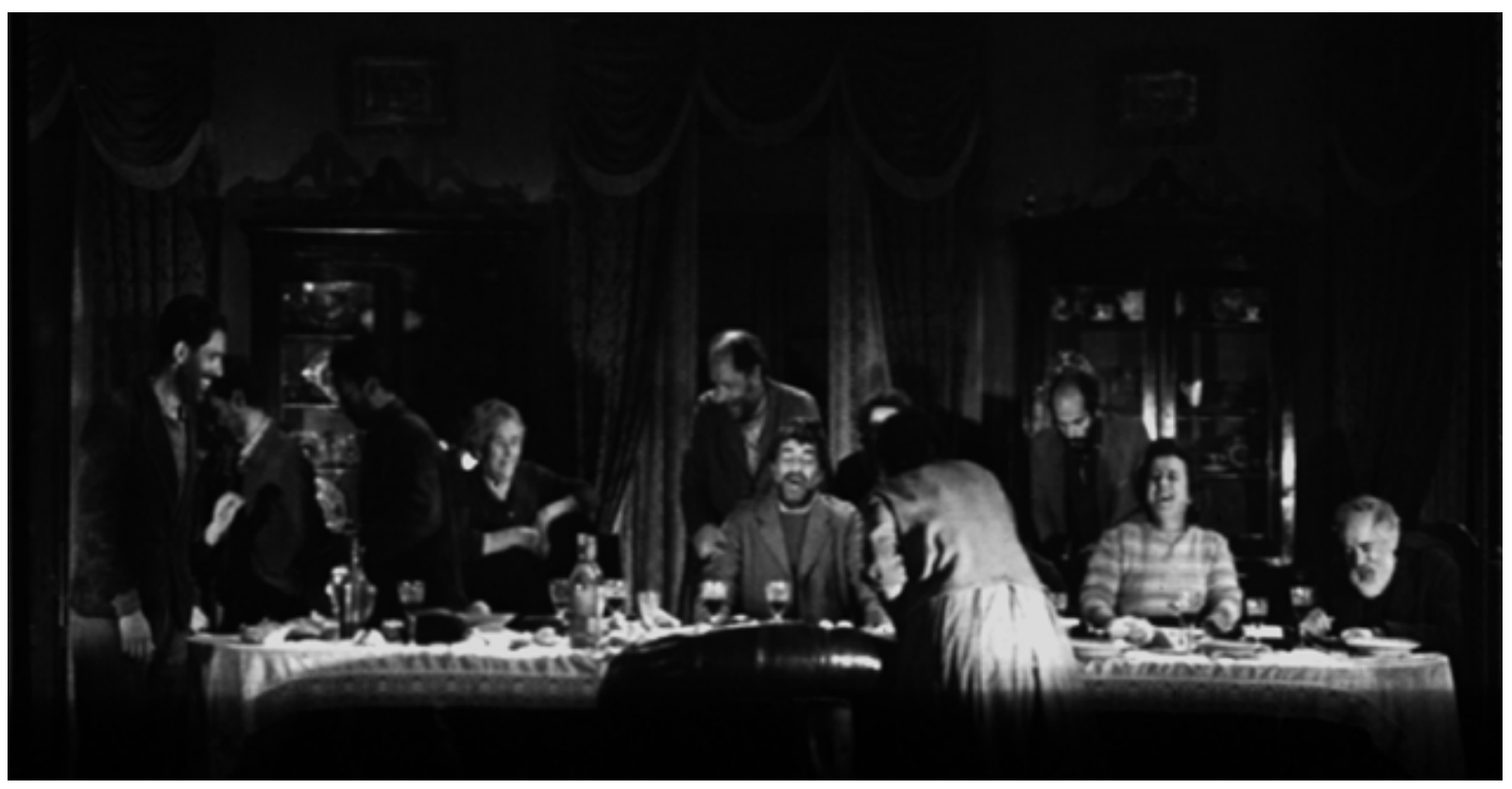

FIGURA 5. Viridiana (Luis Buñuel, 1961). 
Amador, M. L. y Ayala Blanco J. (1985). Cartelera cinematográfica 1950-1959. México: UNAM, Gentro Universitario de Estudios Cinematográficos.

Bajtín, M. M. (1997). Hacia una filosofia del acto ético. De los borradores y otros escritos. Barcelona, España: Anthropos.

BajTín, M. M. (2003). La cultura popular en la Edad Media y el Renacimiento. El contexto de François Rabelais. Madrid, España: Alianza.

Buñuel, L. (1982). Mi último suspiro. México: Plaza y Janes.

De la Colina, J. y Pérez Turrent, T. (1996). Luis Buñuel: Prohibido asomarse al interior. México: CONACULTA.

Hershfield, J. (2001). La mitad de la pantalla: la mujer en el cine mexicano de los años cuarenta. En G. García y D. Maciel (Comp.), El cine mexicano a través de la crítica (pp. 127-151). México: UNAM.

Monsiváis, G. (1997). Amor perdido. México: Era.

Monsiváis, G. (2001). Del peñón de las ánimas al Jagüey de las ruinas. En G. García y D. Maciel (Comp.), El cine mexicano a través de la crítica (pp. 149-154). México: UNAM. Montesinos, R. (Ed.). (2005). Masculinidades emergentes. México: UAM-Iztapalapa.

Stam, R. (1991). Hitchcock and Buñel: Authority, Desire and the Absurd. En W. Raubicheck y W. Srebnick (Eds.), Hitchcock's Rereleased Films. From Rope to Vertigo (pp. 116-138). Detroit, EE.UU.: Weyne State University Press.

Stam, R. (1992). Subversive Pleasures: Bakhtin, Cultural Criticism, and Film. Baltimore, EE.UU.:Johns Hopkins University Press.

Tữón, J. (1998). Mujeres de luz y sombra en el cine mexicano. La construcción de una imagen (1939-1952). México: El Colegio de México.

Voloshinov, V. N. (1992). El marxismo y la filosofia del lenguaje (Los principales problemas del método sociológico en la ciencia del lenguaje). Madrid, España: Alianza.

Zavala, I. (1992). Prólogo. En V. N. Voloshinov, El marxismo y la filosofia del lenguaje. (Los principales problemas del método sociológico en la ciencia del lenguaje) (pp. 10-21). Madrid, España: Alianza. 
Buñuel, L. (Director) \& Alatriste, G. (Productor). (1961). Viridiana. España, México: Unión Industrial Cinematográfica (UNINCI).

Isabel Lincoln Strange Reséndiz (México) es Doctora en Ciencias Políticas y Sociales, línea Comunicación y cultura, por parte de la Facultad de Ciencias Políticas y Sociales de la UNAM. Profesora de la Licenciatura y el Doctorado en Comunicación de la Universidad Anáhuac Norte. Entre sus publicaciones destacan, "La configuración de oriente a través de la representación histórica de Occidente en el cine: el caso de The Four Feathers (Shekhar Kapur, 2002)" (2013), en la revista Xhimai de la Universidad La Salle, y el libro La masculinidad como producción discursiva y la feminidad como silencio en El libro vacío y Los años falsos de Josefina Vicens, publicado por la UAM Iztapalapa en el 2017. Forma parte del Sistema Nacional de Investigadores. 